\title{
EFFECT OF CHITOSAN PRETREATMENT ON SEEDLING GROWTH AND ANTIOXIDANT ENZYME ACTIVITY OF SAFFLOWER (Carthamus tinctorius L.) CULTIVARS UNDER SALINE CONDITIONS
}

\author{
GÜRSOY, M. \\ Guzelyurt Vocational School, Aksaray University, Aksaray, Turkey \\ e-mail: mehtapgrsoy@gmail.com; phone+90-532-404-4948 \\ (Received 22 ${ }^{\text {nd }}$ Apr 2020; accepted 29 $9^{\text {th }}$ Jul 2020)
}

\begin{abstract}
Today, salinity has become a major problem in agricultural areas all over the world. However, plants develop a defense mechanism against stress by increasing various antioxidant enzyme activities in order to tolerate salt and other stress factors. In addition to this mechanism, the effects of stress are attempted to be reduced by various applications that increase enzyme activities. One of these applications is chitosan application. In this study, 4 different doses of chitosan pretreatment ( 0 (control) (Ch1), $0.2 \%$ (Ch2), $0.4 \%$ (Ch3), 0.6\% (Ch4)) were applied to safflower cultivars (Balc1, Linas, Remzibey) for 4 hours under laboratory conditions. For each chitosan application, 50 seeds were germinated under saline conditions (0 (control) (S1), $50 \mathrm{mM}(\mathrm{S} 2), 100 \mathrm{mM}(\mathrm{S} 3), 150 \mathrm{mM}$ (S4)) in petri dish. As a result of the study, it has been determined that chitosan applications provide increases in seedling length, root length, seedling wet weight, root wet weight, germination percentage, total chlorophyll, carotenoid, $\beta$-carotene and lycopene parameters. In the study, it was determined that the most effective chitosan application was Ch3 in terms of the properties examined in stress conditions. According to the research results, it was concluded that chitosan can be considered as a natural material that can positively affect in the defense mechanism of plants under stress conditions.
\end{abstract}

Keywords: abiotic stress, environmental stress, damage, seed germination, seedling development

\section{Introduction}

High soil salinity is an serious factor that limits agricultural production in many regions of the world (Yamaguchi and Blumwald, 2005). Salt soil conditions are also one of the most important environmental stress factors that damage plants significantly (Bulgari et al., 2019; Jafari and Garmdareh, 2019). In addition, stress factors that plants are exposed to divided into two types abiotic and biotic (Bulgari et al., 2019). Salinity, one of the abiotic stress factors, affects plants in two ways. Firstly it causes a decrease in soil water content through osmotic stress. In this way, the water intake of the plant is restricted. The second is that it causes excessive ion intake. In particular, it increases the uptake of $\mathrm{Na}^{+}$and $\mathrm{Cl}^{-}$ions (Abogadallah, 2010). Various environmental stresses cause oxidative damage in plants, causing damage and even death of the plant's cells (Sharma et al., 2012). A variety of reactive oxygen species (ROS) are usually produced in plants under stress conditions. Plants develop molecular defense systems to avoid the effects of damage caused by ROS and limit ROS formation (Rejeb et al., 2014). To reduce oxidative damage in ROS cells, plants develop a defense system containing antioxidant enzymes as well as reduced glutathione, tocopherol, carotenoids and flavonoids such as nonenzymatic ascorbate (Núñez et al., 2003; Azevedo-Neto et al., 2006).

Although germination of seed is one of the critical stages for seedling development and successful crop production, it is a complex process that is very sensitive to the negative effects of environmental conditions (Almansouri et al., 2001; Fan et al., 2013; Kataria et al., 2017). The negative effects of salt application on seed germination and 
seedling development occur as physiological and biochemical changes such as osmotic stress, ion toxicity and oxidative damage (Yu et al., 2013; Alsaeedi et al., 2017; Fang et al., 2017). In plants, salt tolerance can be increased with some environmental applications as well as genetic mechanisms (Razzaq et al., 2020). Therefore, pretreatment applications to seed stimulate the metabolic processes of germination and increase the performance of the seed against various environmental conditions (Jisha et al., 2013; Kataria et al., 2017).

Recently, with the use of biostimulants, the resistance of plants to abiotic stress conditions has been increased and thus agricultural production and quality increase has been provided (Boehme et al., 2008; Mahdavi et al., 2011; Safikhan et al., 2018).

Biostimulators are defined as substances that stimulate the development of the plant obtained from various organic and inorganic substances and also play an important role in reducing the effects of abiotic stress (Boehme et al., 2008; Mahdavi et al., 2011; Du Jardin, 2015). Biostimulant application is one of the approaches to reduce abiotic stress and increase the yield and quality of the product in most plants (Safikhan et al., 2018). Today, one of the biostimulant applications is chitosan application. It is a natural, non-toxic biopolymer obtained by deacetylation of chitosan chitin (Katiyar et al., 2015; Younes and Rinaudo, 2015). In addition, the Crustacea family of the chitin is an important ingredient in crustaceans (crab, shrimp, crayfish, etc.) (No et al., 2002; Gürsoy et al., 2018). It is also stated by the researchers that the chitin is a natural aminopolysaccharide that is abundant in nature (Ravi Kumar, 2000). In addition to being biologically renewable, chitosan is biodegradable, biocompatible, antigenic and non-toxic, and biofunctional structure, and this polymer and the materials obtained using this polymer have been used in biomedical applications such as wound dressing material and drug delivery systems (Kim et al., 2007; Hosseinnejad and Jafari, 2016; Muxika et al., 2017).

In plants, it has been reported that antimicrobial activity, stimulating plant growth and development, inducing chitinase activity and increasing seed yield in the seed coating (Tay, 1993; Tham, 2001; Vasyukova, 2001; Devlieghere et al., 2004). Plant growth, seed germination, chlorophyll content and ion uptake can be increased with chitosan application (Ahmed et al., 2020).

Safflower (Carthamus tinctorius L.) is an annual medicinal and aromatic oilseed crop (Kumar and Kumari, 2005; Moghadam and Mohammadi, 2014; Golkar and Taghizadeh, 2018). In addition, it is an oil plant with flowers in yellow, red, orange, colors, with and without thorns, resistant to drought, with an average oil rate of 30-50\% (Gürsoy, 2019).

In this study, it was aimed to determine the effect of chitosan pretreatment on the development of safflower cultivars, photosynthetic activity and antioxidant enzyme activities in saline conditions.

\section{Materials and methods}

\section{Research material and growth conditions}

Safflower cultivars (Balci, Linas, Remzibey) were obtained from the Central Field Crops Research Institute, Ankara, Turkey. The research was carried out at the Aksaray University Scientific and Technological Research Laboratory (ASÜBTAM). Before commencing the experiment, seeds of cultivars were kept in 5\% sodium hypochlorite solution for 5 minutes for surface sterilization. Then washed with pure water and subjected to 4 hours priming with different concentrations of chitosan (Ch) solutions. Chitosan (Sigma-Aldrich, medium molecular weight, at $85 \%$-acetylated, viscosity $270 \mathrm{cP}$, CAS: $9012-76-4$ ) after dissolving in $0.1 \%$ acetic acid of commercially available 
chitosan [0 (control) (Ch1), 0.2\% (Ch2), 0.4\% (Ch3), 0.6\% (Ch4)]. For each Ch dose, 50 seeds were placed in sterile petri dishes on Whatman No:1 blotting papers and $10 \mathrm{~mL}$ of different doses of salt (0 (control) (S1), $50 \mathrm{mM}$ (S2), 100mM (S3), 150mM (S4)) concentrations were added from solutions containing $\mathrm{NaCl}$ (Merck). Only water was added to the control petri dish. In order to prevent evaporation the petri dishes are wrapped with parafilm. The petri dishes were left to germinate at $24 \pm 1^{0} \mathrm{C}$. The research randomized plots experimental desing were made with 3 replication according to the trial pattern. Measurements and observations were made on the 14th day of the study.

\section{Germination percentage (\%)}

Germination percentage was calculated using the formula below.

$$
\text { Germination } \%=(\text { number of germinated seeds } / \text { total number of seeds }) \times 100
$$

(Siddiqi et al., 2007)

\section{Chlorophyll (mg/g)}

The young leaf samples $(0.25 \mathrm{~g})$ from each safflower cultivar were filtered after homogenizing in $80 \%$ acetone (Merck) and the extracts were filtered with $25 \mathrm{ml}$ with acetone. These samples were read at $663 \mathrm{~nm}$ and $645 \mathrm{~nm}$ wavelength (Beckman coulter DU 730 Life Sciences UV / VIS Spectrophotometer) followed by calculation of chlorophyll using the formula given below (Lichtenthaler, 1983; Amira and Qados, 2011; Kabay and Şensoy, 2016). Before each reading, the device was reset using blind reading.

$$
\begin{aligned}
& \text { Chlorophyll a }(\mathrm{mg} / \mathrm{g})=(12.7 * 663 \mathrm{~nm})-(2.69 * 645 \mathrm{~nm}) * \mathrm{~V} / \mathrm{W} * 10000 \\
& \text { Chlorophyll a }(\mathrm{mg} / \mathrm{g})=(22.91 * 645 \mathrm{~nm})-(4.68 * 663 \mathrm{~nm}) * \mathrm{~V} / \mathrm{W} * 10000 \\
& \text { Total Chlorophyll = Chlorophyll a }+ \text { Chlorophyll b }
\end{aligned}
$$

\section{Carotenoid (mg/g)}

The carotenoid amount was determined according to the Jaspars formula by reading the extract used in determining the chlorophyll amount at $450 \mathrm{~nm}$ wavelength (Beckman Coulter DU 730 Life Sciences UV / VIS Spectrophotometer) (Turfan, 2017).

$$
\text { Carotenoid }=(4.07 \times \text { A450- }(0.0435 \times \text { Chlorophyll a }+0.367 \times \text { Chlorophyll b })(\text { Eq.5 })
$$

\section{$\beta$-Carotene (mg/g)}

$100 \mathrm{mg}$ sample was homogenized for 1 minute in a mixture of $10 \mathrm{ml}$ acetone-hexane (92:3) and filtered. The absorbance of the filtrate at 453, 505 and $663 \mathrm{~nm}$ was recorded. It is preferred in the calculation of carotene amount. (Turfan, 2017).

$$
\text { mg } \beta \text {-Carotene } / 100 \mathrm{mg}=0.0458 \times \mathrm{A} 663+0.372 \times \mathrm{A} 505-0.0806 \times \mathrm{A} 453 \quad \text { (Eq.6) }
$$

\section{Lycopene ( $\mathrm{mg} / \mathrm{g})$}

$100 \mathrm{mg}$ sample was homogenized for 1 minute in a mixture of $10 \mathrm{ml}$ acetone-hexane (92:3) and filtered. The absorbance at 453, 505 and $663 \mathrm{~nm}$ was recorded in the filtered 
extract. The following formula was used to determine the amount of lycopene (Turfan, 2017).

mg Lycopene/100 mg=0.216xA663-0.304xA505+0.452xA453

\section{Statistical analysis}

The experimental data obtained at the end of the research, was subjected to analysis of variance using MSTAT-C computer software. Duncan test was applied to determine the significance levels of the differences between means of applications.

\section{Results}

A statistically significant difference was determined at the level of $P<0.01$ in Cultivars $\times$ Salt doses $\times$ Chitosan doses triple interaction (Table 1) in all the features studied.

Table 1. Variance analysis results on the effect of chitosan pretreatment on seedling growth and antioxidant enzymes of safflower cultivars under saline conditions

\begin{tabular}{|c|c|c|c|c|c|c|c|c|c|c|c|}
\hline \multirow[b]{2}{*}{ Variation sources } & \multirow[b]{2}{*}{ D f } & \multicolumn{2}{|c|}{ Seedling Length } & \multicolumn{2}{|c|}{ Root Length } & \multicolumn{3}{|c|}{\begin{tabular}{|c|}
$\begin{array}{c}\text { Seedling Wet } \\
\text { Weight }\end{array}$ \\
\end{tabular}} & \multicolumn{3}{|c|}{ Root Wet Weight } \\
\hline & & $\begin{array}{l}\text { Mean } \\
\text { square }\end{array}$ & $\mathbf{F}$ & $\begin{array}{l}\text { Mean } \\
\text { squar }\end{array}$ & $\mathbf{F}$ & & $\begin{array}{l}\text { ean } \\
\text { uar } \\
\text { e }\end{array}$ & $\mathbf{F}$ & \begin{tabular}{|c|} 
Mean \\
squar \\
e
\end{tabular} & \multicolumn{2}{|c|}{$\mathbf{F}$} \\
\hline Cultivar & 2 & 0.185 & 1.85 & 0.02 & 1.64 & 0.0 & 002 & $5.78 * *$ & 0.0005 & \multicolumn{2}{|c|}{$3.66 *$} \\
\hline Salt & 3 & 13.21 & $132.57 * *$ & 0.547 & $44.69^{* *}$ & 0.0 & $59 .($ & $59.05 * *$ & 0.003 & \multicolumn{2}{|c|}{$28.00 * *$} \\
\hline Cultivar $\times$ Salt & 6 & 1.123 & $11.26^{* *}$ & 0.038 & $3.104 * *$ & 0.0 & \multicolumn{2}{|c|}{$3.26 * *$} & 0.002 & \multicolumn{2}{|c|}{$13.42 * *$} \\
\hline Chitosan & 3 & 11.04 & $110.76^{* *}$ & 1.702 & \multicolumn{2}{|c|}{$139.15^{* *}$} & \multicolumn{2}{|c|}{$65.52 * *$} & 0.015 & \multicolumn{2}{|c|}{$122.46^{* *}$} \\
\hline Cultivar $\times$ Chitosan & 6 & 0.061 & 0.613 & 0.075 & $6.12 * *$ & 0.0 & \multicolumn{2}{|c|}{1.38} & 0.001 & \multicolumn{2}{|c|}{$6.98 * *$} \\
\hline Salt×Chitosan & 9 & 1.38 & $13.88 * *$ & 0.239 & $19.52 * *$ & 0.0 & \multicolumn{2}{|c|}{$6.03 * *$} & 0.001 & \multicolumn{2}{|c|}{$9.70 * *$} \\
\hline Cultivar $\times$ Salt $\times$ Chitosan & 18 & 0.3 & $3.01 * *$ & 0.068 & $5.546 * *$ & 0.0 & 002 & $4.39 * *$ & 0.001 & \multicolumn{2}{|c|}{$8.25^{* *}$} \\
\hline Error & 96 & \multicolumn{2}{|l|}{0.1} & 0.012 & & 0.00 & 003 & & 0.0001 & & \\
\hline Total & 143 & & & & & & & & & & \\
\hline $\mathrm{CV} \%$ & & & 3.88 & & 3.4 & & 5.59 & & & 7.24 & \\
\hline & & $\begin{array}{r}\text { Germi } \\
\text { perce }\end{array}$ & $\begin{array}{l}\text { ination } \\
\text { entage }\end{array}$ & $\begin{array}{r}\text { Te } \\
\text { chlor }\end{array}$ & $\begin{array}{l}\text { otal } \\
\text { ophyll }\end{array}$ & Carc & otenoid & $\boldsymbol{\beta}-\mathrm{C}$ & arotene & Lyc & copene \\
\hline Variation sources & D f & $\begin{array}{l}\text { Mean } \\
\text { square }\end{array}$ & $\mathbf{F}$ & $\begin{array}{l}\text { Mean } \\
\text { square }\end{array}$ & F & $\begin{array}{l}\text { Mean } \\
\text { square }\end{array}$ & $\mathbf{F}$ & $\begin{array}{c}\text { Mean } \\
\text { square }\end{array}$ & $\mathbf{F}$ & $\begin{array}{l}\text { Mean } \\
\text { square }\end{array}$ & $\mathbf{F}$ \\
\hline Cultivar & 2 & 1.646 & $4.74 *$ & 0.024 & 0.3922 & 0.25 & $6.18^{* *}$ & 0.044 & $32.55 * *$ & 0.008 & $9.18^{* *}$ \\
\hline Salt & 3 & 18.94 & $54.62 * *$ & 7.145 & $115.54 * *$ & 0.239 & $5.92 * *$ & 0.134 & $98.147 * *$ & 0.02 & $24.74 * *$ \\
\hline $\begin{array}{l}\text { Cultivar } \times \\
\text { Salt }\end{array}$ & 6 & 1.741 & $5.02 * *$ & 0.533 & $8.62 * *$ & 0.251 & $6.22 * *$ & 0.012 & $8.57 * *$ & 0.003 & $3.58 * *$ \\
\hline Chitosan & 3 & 15.45 & $44.57 * *$ & 8.061 & $130.35 * *$ & 5.164 & $127.95 * *$ & 0.313 & $229.61 * *$ & 0.118 & $142.33 * *$ \\
\hline $\begin{array}{l}\text { Cultivar } \times \\
\text { Chitosan }\end{array}$ & 6 & 0.137 & 0.395 & 0.124 & 2.008 & 0.343 & $8.48 * *$ & 0.017 & $12.62 * *$ & 0.002 & $2.378 *$ \\
\hline Salt $\times$ Chitosan & 9 & 2.144 & $6.184 * *$ & 0.634 & $10.24 * *$ & 0.792 & $19.62 * *$ & 0.065 & $47.69 * *$ & 0.031 & $37.68 * *$ \\
\hline Cultivar $\times$ Salt $\times$ Chitosan & 18 & 0.882 & $2.543 * *$ & 0.147 & $2.38 * *$ & 0.325 & $8.051 * *$ & 0.019 & $13.66^{* *}$ & 0.003 & $4.03 * *$ \\
\hline Error & 96 & 0.347 & & 0.062 & & 0.04 & & 0.001 & & 0.001 & \\
\hline Total & 143 & --- & -.-- & $\cdots$ & 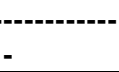 & & ------ & & ---.' & & --- \\
\hline $\mathrm{CV} \%$ & & & .60 & & .02 & & 6.16 & & 5.96 & & 4.74 \\
\hline
\end{tabular}

\footnotetext{
$* * P<0.01, * P<0.05$
} 
When the seedling length feature is examined (Table 2), the longest seedling length was obtained from Balc1 variety in $\mathrm{S} 1 \mathrm{Ch} 3$ application as $10.00 \mathrm{~cm}$. The minimum seedling length was obtained in S4 Ch4 application and Balc1 variety. Generally, the longest seedling length in all cultivars has been obtained in $\mathrm{Ch} 3$ application, and it is determined that chitosan is effective in eliminating the harmful effects of salt while increasing the salt doses. Chitosan application seems to inhibit the effects of salt stress, causing the seedling to grow higher. However, chitosan application had different effects on varieties. For example, in S1 and S4 applications in Balc1 cultivar, it is seen that the seedling height is longest in Ch3. The same is true for the Linas variety. In Remzibey cultivar, Ch3 was found to be the longest seedling length only in S1 application, and in all other salt doses, the longest seedling length was detected in Ch1 application. In the Remzibey cultivar, a positive effect of chitosan applications against salt doses in terms of seedling length could not be determined. Cultivars $\times \mathrm{S}$ doses $\times$ Chitosan doses interaction caused significant difference in seedling length feature at $p<0.01$ level. In this respect, when the study results were examined, it was determined that the harmful effects of salt doses were inhibited by interaction with chitosan. Similarly, salt doses interacted with varieties and showed different reactions in each variety.

Table 2. Average values the effect of chitosan doses applied to safflower cultivars on saline length $(\mathrm{cm})$ under saline conditions

\begin{tabular}{|c|c|c|c|c|c|c|c|c|}
\hline \multirow{3}{*}{ Cultivars } & \multicolumn{8}{|c|}{ Seedling Length $(\mathrm{cm})$} \\
\hline & \multicolumn{4}{|c|}{ S1 } & \multicolumn{4}{|c|}{$\mathbf{S 2}$} \\
\hline & Ch1 & Ch2 & Ch3 & Ch4 & Ch1 & Ch2 & Ch3 & Ch4 \\
\hline Balc1 & $9.53 \mathrm{ab}$ & $7.52 \mathrm{n}-\mathrm{r}$ & $10.00 \mathrm{a}$ & $7.821-q$ & $9.35 \mathrm{a}-\mathrm{c}$ & $8.47 \mathrm{~d}-1$ & $8.63 \mathrm{c}-1$ & 7.94 h-p \\
\hline Linas & $9.56 \mathrm{ab}$ & $8.54 \mathrm{~d}-\mathrm{j}$ & $9.89 \mathrm{a}$ & $8.22 \mathrm{~d}-\mathrm{n}$ & $8.82 \mathrm{~b}-\mathrm{f}$ & $7.77 \mathrm{j}-\mathrm{q}$ & $8.21 \mathrm{~d}-\mathrm{n}$ & $7.90 \mathrm{~h}-\mathrm{q}$ \\
\hline \multirow[t]{3}{*}{ Remzibey } & $8.90 \mathrm{~b}-\mathrm{e}$ & $8.68 \mathrm{c}-\mathrm{h}$ & $9.74 \mathrm{a}$ & 7.96 g-p & $8.75 \mathrm{c}-\mathrm{g}$ & $7.62 \mathrm{~m}-\mathrm{r}$ & $7.63 \mathrm{~m}-\mathrm{r}$ & $7.52 \mathrm{n}-\mathrm{r}$ \\
\hline & \multicolumn{4}{|c|}{ S3 } & \multicolumn{4}{|c|}{ S4 } \\
\hline & Ch1 & Ch2 & Ch3 & Ch4 & Ch1 & Ch2 & Ch3 & Ch4 \\
\hline Balcı & $8.23 \mathrm{~d}-\mathrm{n}$ & $7.74 \mathrm{j}-\mathrm{q}$ & $7.26 \mathrm{p}-\mathrm{s}$ & $7.74 \mathrm{j}-\mathrm{q}$ & $7.74 \mathrm{j}-\mathrm{q}$ & $6.74 \mathrm{st}$ & 8.10 e-o & $6.40 \mathrm{t}$ \\
\hline Linas & $8.92 \mathrm{~b}-\mathrm{d}$ & $7.68 \mathrm{k}-\mathrm{r}$ & $8.30 \mathrm{~d}-\mathrm{n}$ & $8.07 \mathrm{f}-\mathrm{p}$ & $7.841-q$ & $7.12 \mathrm{q}-\mathrm{t}$ & $7.861-q$ & $6.45 \mathrm{t}$ \\
\hline Remzibey & $8.86 \mathrm{~b}-\mathrm{f}$ & $7.661-r$ & $8.50 \mathrm{~d}-\mathrm{k}$ & $8.36 \mathrm{~d}-\mathrm{m}$ & $8.21 \mathrm{~d}-\mathrm{n}$ & $7.29 \mathrm{o}-\mathrm{s}$ & $7.93 \mathrm{~h}-\mathrm{q}$ & $6.92 \mathrm{r}-\mathrm{t}$ \\
\hline LSD $\% 1$ & 0.6786 & & & & & & & \\
\hline
\end{tabular}

According to the Duncan test dissimilar letters in the column show different groups

In terms of root length (Table 3), the longest root length $(3.80 \mathrm{~cm})$ was detected in Remzibey variety and S1 Ch1 application. The shortest root length was determined as $2.59 \mathrm{~cm}$ in Remzibey cultivar and S4 Ch4 application. It is seen that root length increases with increasing Ch doses in all cultivars. However, this increase didn't occur only in the $\mathrm{S} 1$ dose, and it is the dose that does not apply salt since the S1 dose is a control application. In other words, with the application of salt, the effectiveness of chitosan has been revealed and it has been effective in lengthening the root length by inhibiting the negative effects of salt. Although this effect was determined in all varieties, the most effective chitosan application was determined as Ch3. Cultivars $\times \mathrm{S}$ doses $\times$ Chitosan doses were determined statistically significant differences in root length characteristics in terms of $\mathrm{p}<0.01$. With this interaction in all cultivars, root length feature was affected and increased due to salt doses and chitosan doses. 
Table 3. Average values of the effect of chitosan doses applied to safflower varieties under saline conditions on root length $(\mathrm{cm})$

\begin{tabular}{|c|c|c|c|c|c|c|c|c|}
\hline \multirow{3}{*}{ Cultivars } & \multicolumn{8}{|c|}{ Root Length (cm) } \\
\hline & \multicolumn{4}{|c|}{ S1 } & \multicolumn{4}{|c|}{$\mathbf{S 2}$} \\
\hline & Ch1 & Ch2 & Ch3 & Ch4 & Ch1 & Ch2 & Ch3 & Ch4 \\
\hline Balc1 & $3.30 \mathrm{e}-\mathrm{k}$ & $3.39 \mathrm{~d}-\mathrm{j}$ & $3.64 \mathrm{a}-\mathrm{d}$ & $3.22 \mathrm{~g}-\mathrm{n}$ & $3.11 \mathrm{j}-\mathrm{p}$ & $3.20 \mathrm{~g}-\mathrm{n}$ & $3.46 \mathrm{~b}-\mathrm{g}$ & $3.16 \mathrm{~h}-\mathrm{p}$ \\
\hline Linas & $3.29 \mathrm{e}-1$ & $3.30 \mathrm{e}-\mathrm{k}$ & $3.40 \mathrm{c}-1$ & $3.23 \mathrm{f}-\mathrm{n}$ & $3.001-q$ & $3.20 \mathrm{~g}-\mathrm{n}$ & $3.60 \mathrm{a}-\mathrm{d}$ & $3.17 \mathrm{~h}-\mathrm{o}$ \\
\hline \multirow[t]{3}{*}{ Remzibey } & $3.80 \mathrm{a}$ & $3.42 \mathrm{c}-\mathrm{h}$ & $3.50 \mathrm{~b}-\mathrm{f}$ & $3.14 \mathrm{~h}-\mathrm{p}$ & $3.11 \mathrm{j}-\mathrm{p}$ & $3.131-\mathrm{p}$ & $3.64 \mathrm{a}-\mathrm{d}$ & $3.06 \mathrm{k}-\mathrm{q}$ \\
\hline & \multicolumn{4}{|c|}{ S3 } & \multicolumn{4}{|c|}{ S4 } \\
\hline & Ch1 & Ch2 & Ch3 & Ch4 & Ch1 & Ch2 & Ch3 & Ch4 \\
\hline Balc1 & $2.98 \mathrm{n}-\mathrm{q}$ & $3.04 \mathrm{k}-\mathrm{q}$ & $3.72 \mathrm{ab}$ & $2.97 \mathrm{n}-\mathrm{q}$ & $2.99 \mathrm{~m}-\mathrm{q}$ & $3.07 \mathrm{k}-\mathrm{q}$ & $3.45 \mathrm{~b}-\mathrm{g}$ & $2.63 \mathrm{r}$ \\
\hline Linas & $2.97 \mathrm{n}-\mathrm{q}$ & $3.15 \mathrm{~h}-\mathrm{p}$ & $3.66 \mathrm{abc}$ & $2.99 \mathrm{~m}-\mathrm{q}$ & $2.88 \mathrm{pq}$ & $3.52 \mathrm{~b}-\mathrm{e}$ & $3.22 \mathrm{~g}-\mathrm{n}$ & $2.80 \mathrm{qr}$ \\
\hline Remzibey & $3.04 \mathrm{k}-\mathrm{q}$ & $3.15 \mathrm{~h}-\mathrm{p}$ & $3.27 \mathrm{e}-\mathrm{m}$ & $3.06 \mathrm{k}-\mathrm{q}$ & $2.90 \mathrm{o}-\mathrm{q}$ & $3.65 \mathrm{a}-\mathrm{d}$ & $3.48 \mathrm{~b}-\mathrm{g}$ & $2.59 \mathrm{r}$ \\
\hline LSD\%1 & 0.2351 & & & & & & & \\
\hline
\end{tabular}

*According to the Duncan test dissimilar letters in the column show different groups

Seedling wet weight (Table 4) was determined as the most seedling wet weight of $0.45 \mathrm{~g}$ in Linas cultivar in S1 Ch3 application. The minimum seedling wet weight was determined as $0.28 \mathrm{~g}$ in $\mathrm{S} 4 \mathrm{Ch} 1$ application, that is, when $\mathrm{S}$ doses are highest but Ch dose is control, ie $0 \%$. In all other applications, seedling wet weight increased with $\mathrm{Ch}$ application. Cultivars $\times$ S doses $\times$ Chitosan doses were determined statistically significant differences in seedling wet weight in terms of interaction with $\mathrm{p}<0.01$. All cultivars were significantly affected by S and Ch doses. While the application of Ch3 in S2, S3 and S4 in the Balc1 cultivar causes the formation of seedling wet weight the most, Ch3 application in all salt doses in Linas and in S2 and S3 in Remzibey were effective in obtaining the seedling wet weight the most. In $\mathrm{S} 1$ and $\mathrm{S} 4$, the dose of $\mathrm{Ch} 3$ was more effective.

Table 4. Average values the effect of chitosan doses applied to safflower varieties under saline conditions on seedling wet weight $(g)$

\begin{tabular}{|c|c|c|c|c|c|c|c|c|}
\hline \multirow{3}{*}{ Cultivars } & \multicolumn{8}{|c|}{ Seedling Wet Weight (g) } \\
\hline & \multicolumn{4}{|c|}{ S1 } & \multicolumn{4}{|c|}{$\mathbf{S 2}$} \\
\hline & Ch1 & Ch2 & Ch3 & Ch4 & Ch1 & Ch2 & Ch3 & Ch4 \\
\hline Balc1 & $0.41 \mathrm{a}-\mathrm{c}$ & $0.34 \mathrm{~g}-\mathrm{O}$ & $0.38 \mathrm{c}-\mathrm{g}$ & $0.34 \mathrm{~g}-\mathrm{o}$ & 0.33 h-p & $0.40 \mathrm{~b}-\mathrm{e}$ & $0.44 \mathrm{ab}$ & $0.31 \mathrm{k}-\mathrm{p}$ \\
\hline Linas & $0.35 \mathrm{~g}-\mathrm{n}$ & $0.40 \mathrm{~b}-\mathrm{f}$ & $0.45 \mathrm{a}$ & $0.35 \mathrm{~g}-\mathrm{n}$ & 0.34 g-n & $0.37 \mathrm{c}-\mathrm{j}$ & $0.41 \mathrm{~b}-\mathrm{d}$ & $0.33 \mathrm{~h}-\mathrm{p}$ \\
\hline \multirow[t]{3}{*}{ Remzibey } & $0.35 \mathrm{~g}-\mathrm{n}$ & $0.38 \mathrm{c}-\mathrm{h}$ & $0.44 \mathrm{ab}$ & $0.35 \mathrm{f}-\mathrm{m}$ & $0.31 \mathrm{k}-\mathrm{p}$ & $0.37 \mathrm{c}-\mathrm{j}$ & $0.36 \mathrm{~d}-\mathrm{k}$ & $0.33 \mathrm{~g}-\mathrm{o}$ \\
\hline & \multicolumn{4}{|c|}{ S3 } & \multicolumn{4}{|c|}{ S4 } \\
\hline & Ch1 & Ch2 & Ch3 & Ch4 & Ch1 & $\mathrm{Ch} 2$ & Ch3 & Ch4 \\
\hline Balc1 & $0.311-\mathrm{p}$ & $0.35 \mathrm{f}-\mathrm{m}$ & $0.38 \mathrm{c}-\mathrm{g}$ & $0.35 \mathrm{~g}-\mathrm{n}$ & $0.30 \mathrm{~m}-\mathrm{p}$ & $0.36 \mathrm{e}-1$ & 0.35 g-n & $0.32 \mathrm{j}-\mathrm{p}$ \\
\hline Linas & $0.32 \mathrm{j}-\mathrm{p}$ & $0.35 \mathrm{~g}-\mathrm{n}$ & $0.37 \mathrm{c}-1$ & $0.35 \mathrm{~g}-\mathrm{n}$ & $0.30 \mathrm{n}-\mathrm{p}$ & $0.33 \mathrm{~h}-\mathrm{p}$ & 0.34 g-n & $0.31 \mathrm{k}-\mathrm{p}$ \\
\hline Remzibey & $0.321-p$ & $0.36 \mathrm{e}-1$ & $0.35 \mathrm{~g}-\mathrm{n}$ & $0.35 \mathrm{~g}-\mathrm{n}$ & $0.28 \mathrm{p}$ & $0.32 \mathrm{j}-\mathrm{p}$ & 0.33 h-p & 0.29 op \\
\hline $\mathrm{LSD} \% 1$ & 0.04183 & & & & & & & \\
\hline
\end{tabular}

* According to the Duncan test dissimilar letters in the column show different groups 
In the root wet weight feature (Table 5), the maximum root wet weight was determined in Remzibey cultivar in Ch3 application in S1. Although S1 was a control dose, Ch affected root caused an increase in wet weight. However, in other S doses, the root wet weight increased with the increase of $\mathrm{Ch}$. In terms of root wet weight, the most effective Ch doses were $\mathrm{Ch} 2$ and Ch3. Cultivars $\times \mathrm{S}$ doses $\times$ Chitosan doses interaction showed statistically significant difference at $\mathrm{p}<0.01$ in terms of root wet weight.

Table 5. Average values of the effect of chitosan doses applied to safflower varieties under saline conditions on root wet weight $(g)$

\begin{tabular}{|c|c|c|c|c|c|c|c|c|}
\hline \multirow{3}{*}{ Cultivars } & \multicolumn{8}{|c|}{ Root Wet Weight (g) } \\
\hline & \multicolumn{4}{|c|}{ S1 } & \multicolumn{4}{|c|}{ S2 } \\
\hline & Ch1 & Ch2 & Ch3 & Ch4 & Ch1 & Ch2 & Ch3 & Ch4 \\
\hline Balc1 & $0.14 \mathrm{~g}-\mathrm{m}$ & $0.121-n$ & $0.15 \mathrm{f}-1$ & $0.16 \mathrm{~d}-1$ & $0.17 \mathrm{~d}-\mathrm{f}$ & $0.15 \mathrm{e}-\mathrm{k}$ & $0.21 b$ & $0.14 \mathrm{~g}-\mathrm{m}$ \\
\hline Linas & $0.16 \mathrm{~d}-\mathrm{h}$ & $0.14 \mathrm{f}-1$ & $0.18 \mathrm{~cd}$ & $0.15 \mathrm{e}-\mathrm{k}$ & $0.17 \mathrm{~d}-\mathrm{f}$ & $0.18 \mathrm{~cd}$ & $0.18 \mathrm{c}-\mathrm{e}$ & $0.14 \mathrm{~g}-\mathrm{m}$ \\
\hline \multirow[t]{3}{*}{ Remzibey } & $0.15 \mathrm{e}-\mathrm{k}$ & $0.15 \mathrm{~d}-\mathrm{j}$ & $0.24 \mathrm{a}$ & $0.16 \mathrm{~d}-\mathrm{h}$ & $0.13 \mathrm{j}-\mathrm{n}$ & $0.17 \mathrm{~d}-\mathrm{f}$ & $0.16 \mathrm{~d}-\mathrm{h}$ & $0.14 \mathrm{~g}-\mathrm{m}$ \\
\hline & \multicolumn{4}{|c|}{ S3 } & \multicolumn{4}{|c|}{ S4 } \\
\hline & Ch1 & Ch2 & Ch3 & Ch4 & Ch1 & Ch2 & Ch3 & Ch4 \\
\hline Balcı & 0.14 h-n & $0.15 \mathrm{~d}-\mathrm{j}$ & $0.17 \mathrm{~d}-\mathrm{f}$ & $0.15 \mathrm{f}-1$ & $0.121-n$ & $0.131-n$ & $0.18 \mathrm{~cd}$ & $0.131-n$ \\
\hline Linas & $0.131-n$ & $0.16 \mathrm{~d}-\mathrm{h}$ & $0.20 \mathrm{bc}$ & $0.15 \mathrm{e}-\mathrm{k}$ & $0.11 \mathrm{n}$ & $0.15 \mathrm{e}-\mathrm{k}$ & $0.17 \mathrm{~d}-\mathrm{g}$ & $0.121-n$ \\
\hline Remzibey & $0.11 \mathrm{mn}$ & $0.16 \mathrm{~d}-\mathrm{h}$ & $0.21 \mathrm{ab}$ & $0.12 \mathrm{k}-\mathrm{n}$ & $0.15 \mathrm{f}-1$ & $0.15 \mathrm{~d}-\mathrm{j}$ & $0.15 \mathrm{~d}-\mathrm{j}$ & $0.11 \mathrm{n}$ \\
\hline LSD $\% 1$ & 0.02351 & & & & & & & \\
\hline
\end{tabular}

* According to the Duncan test dissimilar letters in the column show different groups

In germination percentage (Table 6), the highest germination rate was determined as 99.97\% in Balc1 cultivar in S2 Ch1 application. The least germination was detected in Linas cultivar and Ch4 application with $95.73 \%$. Cultivars $\times \mathrm{S}$ doses $\times$ Chitosan doses interaction showed statistically significant difference in $p<0.01$ level in terms of germination percentage. In all cultivars, the germination rate decreased with increasing salt doses. However, an increase in germination rate was determined in all cultivars and all $\mathrm{S}$ doses with $\mathrm{Ch}$ applications. For example, in the Remzibey cultivar, it is seen that the germination percentage is highest with the application of $\mathrm{Ch} 3$ at the dose of S4. Similarly, the most germination was determined in $\mathrm{S} 3$ and $\mathrm{S} 4$ in $\mathrm{Ch} 3$ in Balc1 cultivar.

In terms of total chlorophyll (Table 7) Cultivars $\times \mathrm{S}$ doses $\times$ Chitosan doses interaction showed statistically significant difference at $\mathrm{p}<0.01$ level. Differences between varieties were determined with chitosan applications in applied salt doses. Although chlorophyll amount is expected to decrease with increasing salt doses, it has been determined that it increases with chitosan applications. Chitosan had a positive effect by eliminating the negative effect of salt by playing an encouraging role. The highest chlorophyll content was obtained in S1 and Ch1 and the lowest chlorophyll was determined in S4 Ch4 as $1.04 \mathrm{mg} \mathrm{g}^{-1}$. However, the effects of $\mathrm{S}$ and $\mathrm{Ch}$ doses on varieties were in different ways. While S3, S3 and S4 increase Ch3 chlorophyll in the Balc1 cultivar, it is determined that the application of $\mathrm{Ch} 2$ in $\mathrm{S} 1$ and $\mathrm{S} 2$ and $\mathrm{Ch} 4$ in $\mathrm{S} 3$ and $\mathrm{S} 4$ are more effective in linas cultivar. In Remzibey variety cultivar, Ch3 was determined as the most effective application dose in S2, S3 and S4. 
Table 6. Average values of the germination percentage (\%) of chitosan doses applied to safflower varieties under saline conditions

\begin{tabular}{|c|c|c|c|c|c|c|c|c|}
\hline \multirow{3}{*}{ Cultivars } & \multicolumn{8}{|c|}{ Germination percentage $(\%)$} \\
\hline & \multicolumn{4}{|c|}{ S1 } & \multicolumn{4}{|c|}{$\mathbf{S 2}$} \\
\hline & Ch1 & Ch2 & Ch3 & Ch4 & Ch1 & Ch2 & Ch3 & Ch4 \\
\hline Balcı & $99.60 \mathrm{a}-\mathrm{c}$ & $98.73 \mathrm{a}-1$ & $99.60 \mathrm{a}-\mathrm{c}$ & $98.40 \mathrm{~b}-\mathrm{k}$ & $99.97 \mathrm{a}$ & $98.80 \mathrm{a}-1$ & $98.40 \mathrm{~b}-\mathrm{k}$ & $98.57 \mathrm{a}-\mathrm{j}$ \\
\hline Linas & $99.57 \mathrm{a}-\mathrm{d}$ & $99.10 \mathrm{a}-\mathrm{f}$ & $99.80 \mathrm{ab}$ & $97.57 \mathrm{f}-\mathrm{q}$ & $98.43 \mathrm{~b}-\mathrm{k}$ & 97.97 e-p & $98.13 \mathrm{c}-\mathrm{m}$ & $98.07 \mathrm{~d}-\mathrm{o}$ \\
\hline \multirow[t]{3}{*}{ Remzibey } & $99.43 \mathrm{a}-\mathrm{e}$ & $98.80 \mathrm{a}-1$ & $98.33 \mathrm{~b}-1$ & $98.10 \mathrm{c}-\mathrm{n}$ & 97.90 e-p & $96.90 \mathrm{k}-\mathrm{s}$ & $98.27 \mathrm{c}-1$ & $97.73 \mathrm{f}-\mathrm{p}$ \\
\hline & \multicolumn{4}{|c|}{ S3 } & \multicolumn{4}{|c|}{ S4 } \\
\hline & Ch1 & $\mathrm{Ch} 2$ & Ch3 & Ch4 & Ch1 & Ch2 & Ch3 & Ch4 \\
\hline Balcı & $97.43 \mathrm{~h}-\mathrm{q}$ & $97.43 \mathrm{~h}-\mathrm{q}$ & $98.97 \mathrm{a}-\mathrm{h}$ & $96.60 \mathrm{n}-\mathrm{s}$ & $97.53 \mathrm{~g}-\mathrm{q}$ & $96.57 \mathrm{o}-\mathrm{s}$ & $98.40 \mathrm{~b}-\mathrm{k}$ & $96.50 \mathrm{p}-\mathrm{s}$ \\
\hline Linas & $98.07 \mathrm{~d}-\mathrm{o}$ & $96.831-\mathrm{s}$ & $98.40 \mathrm{~b}-\mathrm{k}$ & $97.03 \mathrm{j}-\mathrm{s}$ & 98.00 e-p & $96.73 \mathrm{~m}-\mathrm{s}$ & 97.73 f-p & $95.73 \mathrm{~s}$ \\
\hline Remzibey & $97.331-\mathrm{r}$ & $96.20 \mathrm{q}-\mathrm{s}$ & $99.03 \mathrm{a}-\mathrm{g}$ & $96.93 \mathrm{k}-\mathrm{s}$ & $98.07 \mathrm{~d}-\mathrm{o}$ & $98.07 \mathrm{~d}-\mathrm{o}$ & $98.87 \mathrm{a}-1$ & $95.87 \mathrm{rs}$ \\
\hline LSD $\% 1$ & 1.264 & & & & & & & \\
\hline
\end{tabular}

* According to the Duncan test dissimilar letters in the column show different groups

Table 7. Average values the effect of chitosan doses applied to safflower varieties under saline conditions on total chlorophyll $\left(m g g^{-1} \mathrm{FW}\right)$

\begin{tabular}{|c|c|c|c|c|c|c|c|c|}
\hline \multirow{3}{*}{ Cultivars } & \multicolumn{8}{|c|}{ Total chlorophyll $\left(\mathrm{mg} \mathrm{g}^{-1}\right)$} \\
\hline & \multicolumn{4}{|c|}{ S1 } & \multicolumn{4}{|c|}{$\mathbf{S 2}$} \\
\hline & Ch1 & Ch2 & Ch3 & Ch4 & Ch1 & Ch2 & Ch3 & Ch4 \\
\hline Balc1 & $3.92 \mathrm{a}$ & $2.81 \mathrm{c}-\mathrm{k}$ & $1.95 \mathrm{n}-\mathrm{q}$ & $2.131-q$ & $3.31 \mathrm{bc}$ & $2.41 \mathrm{~g}-\mathrm{p}$ & $3.23 \mathrm{~b}-\mathrm{d}$ & $2.371-p$ \\
\hline Linas & $3.32 \mathrm{bc}$ & $3.04 \mathrm{~b}-\mathrm{g}$ & $2.93 \mathrm{c}-\mathrm{j}$ & $3.02 \mathrm{c}-\mathrm{h}$ & $3.00 \mathrm{c}-1$ & $2.33 \mathrm{j}-\mathrm{q}$ & $2.95 \mathrm{c}-\mathrm{j}$ & $2.04 \mathrm{~m}-\mathrm{q}$ \\
\hline \multirow[t]{3}{*}{ Remzibey } & $3.64 \mathrm{ab}$ & $3.18 \mathrm{~b}-\mathrm{e}$ & $3.08 \mathrm{~b}-\mathrm{f}$ & $3.00 \mathrm{c}-1$ & $2.80 \mathrm{c}-\mathrm{k}$ & $2.05 \mathrm{~m}-\mathrm{q}$ & $2.60 \mathrm{~d}-\mathrm{m}$ & $2.091-q$ \\
\hline & \multicolumn{4}{|c|}{ S3 } & \multicolumn{4}{|c|}{ S4 } \\
\hline & Ch1 & Ch2 & Ch3 & Ch4 & Ch1 & Ch2 & Ch3 & Ch4 \\
\hline Balc1 & $3.31 \mathrm{bc}$ & $1.95 \mathrm{n}-\mathrm{q}$ & $2.70 \mathrm{c}-1$ & $1.99 \mathrm{~m}-\mathrm{q}$ & 2.57 e-n & $1.92 \mathrm{o}-\mathrm{q}$ & $2.23 \mathrm{k}-\mathrm{q}$ & $1.30 \mathrm{rs}$ \\
\hline Linas & $3.26 \mathrm{bc}$ & $1.92 \mathrm{o}-\mathrm{q}$ & $2.51 \mathrm{f}-\mathrm{o}$ & 1.84 p-r & $2.26 \mathrm{k}-\mathrm{q}$ & $1.93 \mathrm{n}-\mathrm{q}$ & $2.151-q$ & $1.14 \mathrm{~s}$ \\
\hline Remzibey & $3.08 \mathrm{~b}-\mathrm{f}$ & $2.04 \mathrm{~m}-\mathrm{q}$ & $2.39 \mathrm{~h}-\mathrm{p}$ & $1.72 \mathrm{qr}$ & $2.55 \mathrm{e}-\mathrm{o}$ & $1.84 \mathrm{p}-\mathrm{r}$ & $2.26 \mathrm{k}-\mathrm{q}$ & $1.04 \mathrm{~s}$ \\
\hline $\mathrm{LSD} \% 1$ & 0.5343 & & & & & & & \\
\hline
\end{tabular}

* According to the Duncan test dissimilar letters in the column show different groups

When the amount of carotenoid is examined (Table 8), the most carotenoid amount is determined as $\mathrm{S} 4 \mathrm{Ch} 3$ as $4.09 \mathrm{mg} \mathrm{g}^{-1}$. The minimum amount of carotenoids was determined as $1.59 \mathrm{mg} \mathrm{g}^{-1}$ in S1 Ch1. It was determined that as the S doses increased, the amount of carotenoids increased in all cultivars. However, it is seen that this increase is higher in Ch3. Cultivars $\times \mathrm{S}$ doses $\times$ Chitosan doses interaction showed statistically significant difference at $\mathrm{p}<0.01$ in terms of carotenoid amount. In all varieties, especially in S2, S3 and S4, the carotenoid decreased slightly in Ch2, but increased in Ch3.

When examined in terms of $\beta$-carotene (Table 9), the most $\beta$-carotene was found as S4 and $\mathrm{Ch} 3$ application in Balc1 cultivar as $0.86 \mathrm{mg} \mathrm{g}^{-1}$. It was determined as at least $\beta$-carotene $0.24 \mathrm{mg} \mathrm{g}^{-1} \mathrm{FW}$ in S1 Ch1 application and Balc1 variety. However, the 
interaction of Cultivars $\times \mathrm{S}$ doses $\times$ Chitosan doses showed a statistically significant difference in $p<0.01$ level in terms of $\beta$-carotene. In terms of $\beta$-carotene, the effects of $S$ and $\mathrm{Ch}$ doses on varieties were determined, and the highest $\beta$-carotene amount in Ch3 was determined in all S doses. Especially in S3, which has the highest salt dosage, the highest $\beta$-carotene was determined in all cultivars.

Table 8. Average values the effect of chitosan doses applied to safflower varieties on saline conditions on the amount of carotenoid $\left(\mathrm{mg} \mathrm{g}^{-1} \mathrm{FW}\right)$

\begin{tabular}{|c|c|c|c|c|c|c|c|c|}
\hline \multirow{3}{*}{ Cultivars } & \multicolumn{8}{|c|}{ Carotenoid ( $\left.\mathrm{mg} \mathrm{g}^{-1} \mathrm{FW}\right)$} \\
\hline & \multicolumn{4}{|c|}{ S1 } & \multicolumn{4}{|c|}{$\mathbf{S 2}$} \\
\hline & Ch1 & Ch2 & Ch3 & Ch4 & Ch1 & Ch2 & Ch3 & Ch4 \\
\hline Balc1 & $1.59 \mathrm{r}$ & $2.67 n-q$ & 3.77 a-e & 3.66 a-h & $2.96 \mathrm{k}-\mathrm{p}$ & $2.66 \mathrm{o}-\mathrm{q}$ & $3.68 \mathrm{a}-\mathrm{f}$ & $3.66 \mathrm{a}-\mathrm{g}$ \\
\hline Linas & $2.21 \mathrm{q}$ & $2.84 \mathrm{~m}-\mathrm{p}$ & $3.65 \mathrm{a}-\mathrm{h}$ & $3.59 \mathrm{a}-1$ & $3.59 \mathrm{a}-1$ & $2.85 \mathrm{~m}-\mathrm{p}$ & $3.58 \mathrm{a}-\mathrm{j}$ & $3.27 \mathrm{e}-\mathrm{m}$ \\
\hline \multirow[t]{3}{*}{ Remzibey } & $3.68 \mathrm{a}-\mathrm{f}$ & $2.72 \mathrm{n}-\mathrm{p}$ & 3.77 a-e & $3.60 \mathrm{a}-1$ & $3.60 \mathrm{a}-1$ & 3.09 1-0 & $3.41 \mathrm{c}-1$ & $3.55 \mathrm{~b}-\mathrm{j}$ \\
\hline & \multicolumn{4}{|c|}{ S3 } & \multicolumn{4}{|c|}{ S4 } \\
\hline & Ch1 & Ch2 & Ch3 & Ch4 & Ch1 & Ch2 & Ch3 & Ch4 \\
\hline Balc1 & $2.96 \mathrm{k}-\mathrm{p}$ & $3.62 \mathrm{a}-\mathrm{h}$ & $3.45 \mathrm{c}-\mathrm{k}$ & $3.33 \mathrm{~d}-\mathrm{m}$ & $2.911-\mathrm{p}$ & $3.31 \mathrm{~d}-\mathrm{m}$ & $3.81 \mathrm{a}-\mathrm{d}$ & $3.24 \mathrm{f}-\mathrm{m}$ \\
\hline Linas & $3.14 \mathrm{~h}-\mathrm{o}$ & $3.07 \mathrm{j}-\mathrm{o}$ & $3.81 \mathrm{a}-\mathrm{d}$ & $3.14 \mathrm{~h}-\mathrm{o}$ & $2.56 \mathrm{pq}$ & $3.15 \mathrm{~g}-\mathrm{o}$ & $3.99 \mathrm{ab}$ & $3.26 \mathrm{e}-\mathrm{m}$ \\
\hline Remzibey & $2.94 \mathrm{k}-\mathrm{p}$ & $3.27 \mathrm{e}-\mathrm{m}$ & $3.88 \mathrm{a}-\mathrm{c}$ & $3.17 \mathrm{f}-\mathrm{n}$ & $2.65 \mathrm{o}-\mathrm{q}$ & $3.01 \mathrm{k}-\mathrm{p}$ & $4.09 \mathrm{a}$ & $3.03 \mathrm{k}-\mathrm{p}$ \\
\hline LSD $\% 1$ & 0.4292 & & & & & & & \\
\hline
\end{tabular}

* According to the Duncan test dissimilar letters in the column show different groups

Table 9. Average values the effect of chitosan doses applied to safflower varieties on saline conditions on the amount of $\beta$-carotene $\left(\mathrm{mg} \mathrm{g}^{-1} \mathrm{FW}\right)$

\begin{tabular}{|c|c|c|c|c|c|c|c|c|}
\hline \multirow{3}{*}{ Cultivars } & \multicolumn{8}{|c|}{$\beta$-Caroten $\left(\mathrm{mg} \mathrm{g}^{-1} \mathrm{FW}\right)$} \\
\hline & \multicolumn{4}{|c|}{ S1 } & \multicolumn{4}{|c|}{ S2 } \\
\hline & Ch1 & Ch2 & Ch3 & Ch4 & Ch1 & Ch2 & Ch3 & Ch4 \\
\hline Balcı & $0.24 \mathrm{p}$ & 0.50 1-1 & $0.69 \mathrm{bc}$ & $0.69 \mathrm{bc}$ & 0.39 no & $0.37 \mathrm{o}$ & $0.65 b-f$ & $0.65 \mathrm{~b}-\mathrm{e}$ \\
\hline Linas & $0.69 \mathrm{~b}$ & $0.42 \mathrm{~m}-\mathrm{o}$ & $0.69 \mathrm{~b}$ & $0.64 b-f$ & $0.511-1$ & $0.48 \mathrm{k}-\mathrm{m}$ & $0.84 \mathrm{a}$ & $0.68 \mathrm{~b}-\mathrm{e}$ \\
\hline \multirow[t]{3}{*}{ Remzibey } & 0.52 1-1 & 0.36 o & $0.66 \mathrm{~b}-\mathrm{e}$ & $0.60 \mathrm{e}-\mathrm{h}$ & $0.55 \mathrm{~h}-\mathrm{k}$ & $0.48 \mathrm{j}-\mathrm{m}$ & $0.71 \mathrm{~b}$ & $0.63 \mathrm{~b}-\mathrm{g}$ \\
\hline & \multicolumn{4}{|c|}{ S3 } & \multicolumn{4}{|c|}{ S4 } \\
\hline & Ch1 & Ch2 & Ch3 & Ch4 & Ch1 & Ch2 & Ch3 & Ch4 \\
\hline Balcı & $0.68 \mathrm{~b}-\mathrm{d}$ & $0.67 \mathrm{~b}-\mathrm{e}$ & $0.66 \mathrm{~b}-\mathrm{e}$ & $0.65 \mathrm{~b}-\mathrm{e}$ & $0.61 \mathrm{c}-\mathrm{h}$ & $0.68 \mathrm{~b}-\mathrm{e}$ & $0.86 \mathrm{a}$ & $0.54 \mathrm{~h}-\mathrm{k}$ \\
\hline Linas & $0.69 \mathrm{bc}$ & $0.69 \mathrm{bc}$ & $0.82 \mathrm{a}$ & $0.65 \mathrm{~b}-\mathrm{f}$ & $0.57 \mathrm{f}-1$ & $0.71 \mathrm{~b}$ & $0.82 \mathrm{a}$ & $0.56 \mathrm{~g}-\mathrm{j}$ \\
\hline Remzibey & $0.65 \mathrm{~b}-\mathrm{f}$ & $0.65 \mathrm{~b}-\mathrm{f}$ & $0.85 \mathrm{a}$ & $0.60 \mathrm{~d}-\mathrm{h}$ & $0.55 \mathrm{~h}-\mathrm{k}$ & $0.70 \mathrm{~b}$ & $0.80 \mathrm{a}$ & $0.451-n$ \\
\hline $\mathrm{LSD} \% 1$ & 0.0678 & & & & & & & \\
\hline
\end{tabular}

* According to the Duncan test dissimilar letters in the column show different groups

When the study results are examined in terms of lycopene (Table 10), the most lycopene was determined as $0.81 \mathrm{mg} \mathrm{g}^{-1}$ in Linas and Remzibey varieties in S4 and Ch3. The least lycopene was determined as $0.44 \mathrm{mg} \mathrm{g}^{-1}$ in S2 Ch1. Especially in S3 and S4 doses in which salt doses increased, the highest lycopene in Ch3 was determined. As in carotene, S4, which has a high salt dose in lycopene, has the highest lycopene content in all varieties in $\mathrm{Ch} 3$ application. 
Table 10. Average values the effect of chitosan doses applied on safflower varieties on saline conditions on the amount of lycopene $\left(\mathrm{mg} \mathrm{g}^{-1} \mathrm{FW}\right)$

\begin{tabular}{|c|c|c|c|c|c|c|c|c|}
\hline \multirow{3}{*}{ Cultivars } & \multicolumn{8}{|c|}{ Lycopene ( $\mathrm{mg} \mathrm{g}^{-1}$ FW) } \\
\hline & \multicolumn{4}{|c|}{ S1 } & \multicolumn{4}{|c|}{$\mathbf{S 2}$} \\
\hline & Ch1 & Ch2 & Ch3 & Ch4 & Ch1 & Ch2 & Ch3 & Ch4 \\
\hline Balc1 & $0.55 \mathrm{f}-\mathrm{k}$ & $0.60 \mathrm{~d}-\mathrm{g}$ & $0.60 \mathrm{c}-\mathrm{g}$ & $0.69 \mathrm{~b}$ & 0.441 & $0.60 \mathrm{c}-\mathrm{g}$ & $0.63 \mathrm{~b}-\mathrm{f}$ & $0.62 \mathrm{~b}-\mathrm{g}$ \\
\hline Linas & $0.511-1$ & $0.57 \mathrm{~d}-1$ & $0.62 \mathrm{~b}-\mathrm{g}$ & $0.64 \mathrm{~b}-\mathrm{e}$ & $0.49 \mathrm{kl}$ & $0.64 \mathrm{~b}-\mathrm{e}$ & $0.60 \mathrm{c}-\mathrm{g}$ & $0.63 \mathrm{~b}-\mathrm{f}$ \\
\hline \multirow[t]{3}{*}{ Remzibey } & $0.52 \mathrm{~h}-\mathrm{k}$ & $0.64 \mathrm{n}-\mathrm{d}$ & $0.60 \mathrm{~d}-\mathrm{g}$ & $0.64 \mathrm{~b}-\mathrm{d}$ & $0.54 \mathrm{~g}-\mathrm{k}$ & $0.61 \mathrm{~b}-\mathrm{g}$ & $0.59 \mathrm{~d}-1$ & $0.64 \mathrm{~b}-\mathrm{e}$ \\
\hline & \multicolumn{4}{|c|}{ S3 } & \multicolumn{4}{|c|}{ S4 } \\
\hline & Ch1 & Ch2 & Ch3 & Ch4 & Ch1 & Ch2 & Ch3 & Ch4 \\
\hline Balc1 & $0.49 \mathrm{j}-1$ & $0.60 \mathrm{~d}-\mathrm{h}$ & $0.60 \mathrm{~d}-\mathrm{h}$ & $0.59 \mathrm{~d}-\mathrm{h}$ & $0.56 \mathrm{e}-\mathrm{k}$ & $0.60 \mathrm{c}-\mathrm{g}$ & $0.78 \mathrm{a}$ & $0.56 \mathrm{~d}-\mathrm{k}$ \\
\hline Linas & $0.55 \mathrm{f}-\mathrm{k}$ & $0.60 \mathrm{c}-\mathrm{g}$ & $0.68 \mathrm{bc}$ & $0.57 \mathrm{~d}-1$ & $0.62 \mathrm{~b}-\mathrm{g}$ & $0.57 \mathrm{~d}-\mathrm{j}$ & $0.81 \mathrm{a}$ & $0.56 \mathrm{~d}-\mathrm{k}$ \\
\hline Remzibey & $0.54 \mathrm{~g}-\mathrm{k}$ & $0.60 \mathrm{c}-\mathrm{g}$ & $0.78 \mathrm{a}$ & $0.59 \mathrm{~d}-\mathrm{h}$ & $0.63 \mathrm{~b}-\mathrm{f}$ & $0.58 \mathrm{~d}-1$ & $0.81 \mathrm{a}$ & $0.59 \mathrm{~d}-\mathrm{h}$ \\
\hline $\mathrm{LSD} \% 1$ & \multicolumn{8}{|c|}{0.06786} \\
\hline
\end{tabular}

* According to the Duncan test dissimilar letters in the column show different groups

\section{Discussion}

In this study, in which different doses of salt were applied with different doses of chitosan pretreatment to the safflower varieties, although the results were evaluated, there was a decrease in some morphological features due to the increase of salt doses, and with the application of chitosan, the characteristics of seedling length, root length, root wet weight, seedling wet weight and germination rate an increase was observed. However, there are increases in biochemical properties with the effect of chitosan application in stress conditions. The most effective chitosan dose was determined as $\mathrm{Ch} 3$ in all the properties studied. Ma et al. (2012) reported that application of $0.0625 \%$ oligochitosan to the nutrient solution in which wheat seeds were grown reduces the negative effect of salt stress. Jabeen and Ahmad (2013), applied chitosan to sunflower and safflower varieties under salty conditions. As a result of the study, they reported that low concentration of chitosan application caused increase in germination parameters of both cultivars. In the study conducted by Sheikha and Al-Malki (2011), they reported that chitosan applications had an effect on the plant's growth parameters, such as seedling and root height, wet and dry weight. Al-Tawaha et al. (2018), $81.94 \mathrm{~cm}$ in plant height control application, $84.06 \mathrm{~cm}$ in $30 \mathrm{mg} / \mathrm{L}$ chitosan application, $84.38 \mathrm{~cm}$ in $60 \mathrm{mg} / \mathrm{L}$ chitosan application, $84.81 \mathrm{in} 60 \mathrm{mg} / \mathrm{L}$ chitosan application, they reported that they had determined in $\mathrm{cm}$. Salt stress affects chlorophyll metabolism and causes a significant decrease in chlorophyll production (Qin et al., 2019). Chlorophyll content is widely used in plants as an indicator of abiotic stress tolerance. In addition, chlorophyll decreases in plants exposed to stresses such as salinity, as a result of which growth is delayed (Safikhan et al., 2018). In recent studies, it has been reported by researchers that chitosan increases chlorophyll content in soybean and peanuts (Dzung, 2005). Yahyaabadi et al. (2016), applied chitosan to fenugreek plants under salt stress. As a result of the study, they reported that the application was effective in promoting plant growth by reducing salt stress on the water content of the leaf and photosynthetic pigment parameters. Turfan (2017), applied various abiotic stresses (salt, heavy metal, drought and lime) to the spinach plant. As a result of the study, it was reported that chlorophyll a, b, total chlorophyll and carotenoid, 
$\beta$-carotene and lycopene content increased in drought and lime stress applications. Stahl and Sies (2003), reported that carotenoids are pigments that play a very important role in the protection of plants against photooxidative processes in plants and are antioxidants that play an extremely active role in eliminating the harmful effects of free oxygen radicals. In addition to having antioxidant capacity, carotenoids also play a very important role in reacting to various stress conditions (Boba et al., 2011). In plants under stress, the amount of photosynthetic pigment consisting of chlorophyll a, chlorophyll b, total chlorophyll and carotenoid varies depending on factors such as species, type of stress, duration of stress, the period of the plant in the life cycle, and the intensity of stress (Turfan, 2017). Linic et al. (2019), it is suggested that carotenoids, which are specific metabolites, can play a positive role as natural substances in stress management in tolerant species. Rahman et al. (2018), reported that the application of chitosan to the strawberry plant in the form of a spray causes an increase in the carotenoid content of the plant. $\beta$-carotene is an organic red-orange colored pigment that is abundant in plants (Pop et al., 2019). Falcinelli et al. (2017), reported that appropriate doses of salt cause increased phenolic compounds in rapeseed. He et al. (2020), reported that $\mathrm{NaCl}$ and $\mathrm{CaCl}_{2}$ application can be used as a strategy that will increase the antioxidant activity through the accumulation of carotenoids as a result of their study in corn plant. In this study, it was determined that pre-application of chitosan to the seeds of safflower varieties against salt stress promotes the strengthening of the defense system by causing the enzyme activities of the varieties to increase.

\section{Conclusion}

In this study, besides the negative effects of salt doses, the positive effects of chitosan application, safflower varieties were affected at different levels. The most advantageous results were obtained from the Remzibey variety in terms of morphological (seedling length, root length, seedling wet weight, root wet weight, germination percentage) and biochemical (chlorophyll, carotenoid, $\beta$-carotene and lycopene) parameters. In addition, it has been determined that chitosan plays a role in promoting the increase of enzyme activities, which is the defense mechanism of plants under stress conditions. In this study, the third dose of chitosan (Ch3) caused the most advantageous results. As a result of the study, it was concluded that chitosan can be evaluated as a natural material that can be effective in the defense mechanism of plants under stress conditions. It has been concluded that with the pretreatment of chitosan in regions with salty soil conditions in the world, the germination and seedling development of plants can be increased accordingly it was concluded that yield and quality can be increased. However, applications should be made in other plants and under various stress conditions and their results should be evaluated.

\section{REFERENCES}

[1] Abogadallah, G. M. (2010): Antioxidative defense under salt stres. - Plant Signaling \& Behavior 5(4): 369-374. DOI: 10.4161/psb.5.4.10873.

[2] Ahmed, K. B. M., Khan, M. M. A., Siddiqui, H., Jahan, A. (2020): Chitosan and its oligosaccharides, a promising option for sustainable crop production- a review. Carbohydrate Polymers 227: 115331.

https://doi.org/10.1016/j.carbpol.2019.115331. 
[3] Almansouri, M., Kinet, J. M., Lutts, S. (2001): Effect of salt and osmotic stresseson germination in durum wheat (Triticum durum Desf.). - Plant Soil 231: 243-254.

[4] Alsaeedi, A. H., El-Ramady, H., Alshaal, T., El-Garawani, M., Elhawat, N., Almohsen, M. (2017): Engineered silica nanoparticles alleviate the detrimental effects of $\mathrm{Na}+$ stress on germination and growth of common bean (Phaseolus vulgaris). - Environ. Sci. Pollut. Res. 24: 21917-21928.

[5] Al-Tawaha, A. R., Turk, M. A., Al-Tawaha, A. R. M., Alu'datt, M. H., Wedyan, M., AlRamamneh, E. A. M., Hoang, A. T. (2018): Using Chitosan to Improve Growth of Maize Cultivars Under Salinity Conditions. - Bulgarian Journal of Agricultural Science 24(3): 437-442.

[6] Amira, M. S., Qados, A. (2011): Effect of salt stress on plant growth and metabolism of bean plant Vicia faba (L.). - Journal of The Saudi Society of Agricultural Sciences 10: 715.

[7] Azevedo-Neto, A. D., Prisco, J. T., Eneas-Filho, J., Abreu, C. E. B., Filho, E. G. (2006): Effect of salt stress on antioxidant enzymes and lipid peroxidation in leaves and roots of salt-tolerant and salt-sensitive maize genotypes. - Environ. Exp. Bot. 56: 87-94.

[8] Boba, A., Kulma, A., Kostyn, K., Starzycki, M., Starzycka, E., Szopa, J. (2011): The influence of carotenoid biosynthesis modification on the Fusarium culmorum and Fusarium oxysporum resistance in flax. - Physiological and Molecular Plant Pathology 76(1): 39-47. https://doi.org/10.1016/j.pmpp.2011.06.002.

[9] Boehme, M., Schevschenko, Y., Pinker, I. (2008): Use of biostimulators to reduce abiotics stress in cucumber plants (Cucumis sativus L.). - Acta Hortic 774: 339-344. DOI:10.17660/ActaHortic.2008.774.46.

[10] Bulgari, R., Franzoni, G., Ferrante, A. (2019): Biostimulants Application in Horticultural Crops under Abiotic Stress Conditions. - Agronomy 9(306): 1-30. DOI:10.3390/agronomy9060306.

[11] Devlieghere, F., Vermeulen, A., Debevere, J. (2004): Chitosan: antimicrobial activity, interactions with food components and applicability as a coating on fruit and vegetables. Food Microbiol. 21(6): 703-714.

[12] Du Jardin, P. (2015): Plant biostimulants: Definition, concept, main categories and regulation. - Sci. Hortic. (Amst.) 196: 3-14. DOI:10.1016/j.scienta.2015.09.021.

[13] Dzung, N. A. (2005): Application of chitin, chitosan and their derivatives for agriculture in Vietnam. - Journal of Chitin and Chitosan Science 10: 109-113.

[14] Falcinelli, B., Sileoni, V., Marconi, O., Perretti, G., Quinet, M., Lutts, S., Benincasa, P. (2017): Germination under Moderate Salinity Increases Phenolic Content and Antioxidant Activity in Rapeseed (Brassica napus var. oleifera Del.) Sprouts. - Molecules 22: 1377. DOI:10.3390/molecules22081377.

[15] Fan, H. F., Du, C. X., Ding, L., Xu, Y. L. (2013): Effects of nitric oxide on the germination of cucumber seeds and antioxidant enzymes under salinity stress. - Acta Physiol. Plant. 35: 2707-2719.

[16] Fang, Y., Li, J., Jiang, J., Geng, Y., Wang, J., Wang, Y. (2017): Physiological and epigenetic analyses of Brassica napus seed germination in response to salt stress. - Acta Physiol. Plant. 39: 128.

[17] Golkar, P., Taghizadeh, M. (2018): In vitro evaluation of phenolic and osmolite compounds, ionic content, and antioxidant activity in safflower (Carthamus tinctorius L.) under salinity stress. - Plant Cell Tissue Organ Cult 134: 357-368.

[18] Gürsoy, M., Sargin, I., Mujtaba, M., Akyuz, B., Ilk, S., Akyuz, L., Kaya, M., Cakmak, Y. S., Salaberria, A. M., Labidi, J., Erdem, N. (2018): False flax (Camelina sativa) seed oil as suitable ingredient for the enhancement of physicochemical and biological properties of chitosan films. - International Journal of Biological Macromolecules 114: 1224-1232.

[19] Gürsoy, M. (2019): The effect of different giberellic ac1d doses on germination properties of safflower (Carthamus tinctorius L.) cultivars. - International conference on Food, 
Agriculture and animal Husbandry. September 19-22 2019, pp. 395-404, Gaziantep/Türkiye.

[20] He, W., Wang, Y., Luo, H., Li, D., Liu, C., Song, J., Zhang, Z., Liu, C., Niu, L. (2020): Effect of $\mathrm{NaCl}$ stress and supplemental $\mathrm{CaCl}_{2}$ on carotenoid accumulation ingerminated yellow maize kernels. - Food Chemistry 309: 125779.

https://doi.org/10.1016/j.foodchem.2019.125779.

[21] Hosseinnejad, M., Jafari, S. M. (2016): Evaluation of different factors affecting antimicrobial properties of chitosan. - International Journal of Biological Macromolecules 85: 467-475. DOI:10.1016/j.ijbiomac.2016.01.022.

[22] Jabeen, N., Ahmad, R. (2013): The activity of antioxidant enzymes in response to salt stress in safflower (Carthamus tinctorius L.) and sunflower (Helianthus annuus L.) seedlings raised from seed treated with chitosan. - J Sci Food Agric. 93: 1699-1705. DOI:10.1002/jsfa.5953.

[23] Jafari, S., Garmdareh, S. E. H. (2019): Effects of salinity on morpho-physiological, and biochemical characteristics of stock plant (Matthiola incana L.). - Scientia Horticulturae 257: 108731. https://doi.org/10.1016/j.scienta.2019.108731.

[24] Jisha, K. C., Vijayakumari, K., Puthur, J. T. (2013): Seed priming for abiotic stress tolerance: an overview. - Acta Physiol Plant 35: 1381-1396.

DOI:10.1007/s11738-012-1186-5.

[25] Kabay, T., Şensoy, S. (2016): Kuraklık Stresinin Bazı Fasulye Genotiplerinde Oluşturduğu Enzim, Klorofil ve İyon Değişimleri. - YYU J AGR SCI 26(3): 380-395.

[26] Kataria, S., Baghel, L., Guruprasad, K. N. (2017): Pre-treatment of seeds with static magnetic field improves germination and early growth characteristics under salt stress in maize and soybean. - Biocatalysis Agric. Biotechnol. 10: 83-90.

[27] Katiyar, D., Hemantaranjan, A., Singh, B. (2015): Chitosan as a promising natural compound to enhance potential physiological responses in plant: a review. - Indian J Plant Physiol 20: 1-9.

[28] Kim, K. W., Thomas, R. L. (2007): Antioxidative activityof chitosans with varying molecular eights. - Food Chem 101: 308-313.

[29] Kumar, J. V., Kumari, B. D. R. (2005): Effect of phytohormones on multiple shoot bud induction in cv. NARI-6 of safflower (Carthamus tinctorius L.). - J. Plant Biotechnol. 7: 149-153.

[30] Lichtenthaler, H. K., Wellburn, A. R. (1983): Determinations of total careteonids and chlorophylls $\mathrm{a}$ and $\mathrm{b}$ of leaf extracts in different solvents. - Biomchem. Soc. Transac. 11: 591-592.

[31] Linic, I., Samec, D., Grúz, J., Vujcic Bok, V., Strnad, M., Salopek-Sondi, B. (2019): Involvement of Phenolic Acids in Short-Term Adaptation to Salinity Stress is SpeciesSpecific among Brassicaceae. - Plants 8(6): 155. DOI:10.3390/plants8060155.

[32] Ma, L., Li, Y., Yu, C., Wang, Y., Li, X., Li, N., Bu, N. (2012): Alleviation of exogenous oligochitosan on wheat seedlings growth under salt stress. - Protoplasma 249(2): 393-399.

[33] Mahdavi, B., Modarres, S. S., Aghaalikhani, M., Sharifi, M., Dolatabadian, A. (2011): Chitosan improves osmotic potential tolerance in safflower (Carthamus tinctorius L.) seedlings. - J Crop Improve 25: 728-741.

[34] Moghadam, A. K., Mohammadi, K. (2014): A laboratory and glasshouse evaluation of ascorbic and salicylic acid effect on germination traits and grain yield of safflower cultivars. - Environmental and Experimental Biology 12: 39-42.

[35] Muxika, A., Etxabide, A., Uranga, J., Guerrero, P., de la Caba, K. (2017): Chitosan as a bioactive polymer: Processing, properties and applications. - International Journal of Biological Macromolecules 105: 1358-1368. DOI:10.1016/j.ijbiomac.2017.07.087.

[36] No, H. K., Park, N. Y., Lee, S. H., Meyers, S. P. (2002): Antibacterial activity of chitosans and chitosan oligomers with different molecular weights. - Int J Food Microbiol 74: 6572 . 
[37] Núnnez, M., Mazzafera, P., Mazorra, L. M., Siqueira, W. J., Zullo, M. A. T. (2003): Influence of a brassinosteroid analogue on antioxidant enzymes in rice grown in culture medium with $\mathrm{NaCl}$. - Plant Biol. 47(1): 67-70.

[38] Pop, F., Năsu1, D., Voşgan, Z., Mihali, C., Butean, C. (2019): Chemical Stabilization of Fats Rich in Long Chain Polyunsaturated Fatty Acids by Antioxidants Addition. - Studia Ubb Chemia, LXIV 1: 173-184. DOI:10.24193/subbchem.2019.1.14.

[39] Qin, C., Ahanger, M. A., Zhou, J., Ahmed, N., Wei, C., Yuan, S., Ashraf, M., Zhang, L. (2019): Beneficial role of acetylcholine in chlorophyll metabolism and photosynthetic gas exchange in Nicotiana benthamiana seedlings under salinity stres. - Plant Biology 22(3): 357-365. DOI:10.1111/plb.13079.

[40] Rahman, M., Mukta, J. A., Sabir, A. A., Gupta, D. R., Mohi-Ud-Din, M., Hasanuzzaman, M., Islam, M. T. (2018): Chitosan biopolymer promotes yield and stimulates accumulation of antioxidants in strawberry fruit. - PloS One 13(9): e0203769. https://doi.org/10.1371/journal.pone.0203769.

[41] Ravi Kumar, M. N. V. (2000): A review of chitin and chitosan applications. - Reactive and Functional Polymers 46(1): 1-27.

[42] Razzaq, A., Ali, A., Safdar, L. B., Zafar, M. M., Rui, Y., Shakeel, A., Shaukat, A., Ashraf, M., Gong, W., Yuan, Y. ( 2020): Salt stress induces physiochemical alterations in rice grain composition and quality. - Journal of Food Science 85(1): 14-20. DOI:10.1111/1750-3841.14983.

[43] Rejeb, K. B., Abdelly, C., Savouré, A. (2014): How reactive oxygen species and proline face stress together. - Plant Physiol Biochem. 80: 278-284.

[44] Safikhan, S., Khoshbakht, K., Chaichi, M. R., Motesharezadeh, A. A. B. (2018): Role of chitosan on the growth, physiological parameters and enzymatic activity of milk thistle (Silybum marianum (L.) Gaertn.) in a pot experiment. - Journal of Applied Research on Medicinal and Aromatic Plants 10: 49-58. DOI:10.1016/j.jarmap.2018.06.002.

[45] Sharma, P., Jha, A. B., Dubey, R. S., Pessarakli, M. (2012): Reactive oxygen species, oxidative damage, and antioxidative defense mechanism in plants under stressful conditions. - Journal of Botany: 217037. https://doi. org/10.1155/2012/217037.

[46] Sheikha, S. A., Al-Malki, F. M. (2011): Growth and chlorophyll responses of bean plants to the chitosan applications. - European Journal of Scientific Research 50(1): 124-134.

[47] Siddiqi, E., Ashraf, M., Aisha, A. N. (2007): Variation in seed germination and seedling growth in some diverse line of safflower (Carthamus tinctorius L.) under salt stress. - Pak J Bot 39: 1937-1944.

[48] Stahl, W., Sies, H. (2003): Antioxidant Activity of Carotenoids. - Molecular Aspects of Medicine 24: 345-351. DOI:10.1016/S0098-2997(03)00030-X.

[49] Tay, L. P., Khoh, L. K., Loh, C. S., Khor, E. (1993): Alginate-chitosan coacervation in production of artificial seeds. - Biotechnol. Bioeng. 42(4): 449-454.

[50] Tham, L. X., Nagasawa, N., Matsuhashi, S., Ishioka, N. S., Ito, T., Kume, T. (2001): Effect of radiation-degraded chitosan on plants stressed with vanadium. - Radiat. Phys. Chem. 61: 171-175.

[51] Turfan, N. (2017): Effect of Some Abiotic Stress Factories on Savrun Spinach (Spinacea oleracea L.). - Turkish Journal Of Agriculture - Food Science And Technology 5(6): 660667.

[52] Vasyukova, N. I., Zinoveva, S. V., Il'inskaya, L. I., Perekhod, E. A., Chalenko, G. I., Gerasimova, N. G., Il'ina, A. V., Valamov, V. P., Ozeretskovskaya, O. L. (2001): Appl. Biochem. Microbiol. 37: 103-109.

[53] Yahyaabadi, H. M., Asgharipour, M. R., Basiri, M. (2016): Role of chitosan in improving salinity resistance through some morphological and physiological characteristics in fenugreek (Trigonella foenum-graecum L.). - J Sci Technol Greenhouse Cult 7(25): 165174.

[54] Yamaguchi, T., Blumwald, E. (2005): Developing salt-tolerant crop plants: challenges and opportunities. - Trends Plant Sci 10: 615-620. 


$$
\text { - } 6603 \text { - }
$$

https://doi.org/10.1016/j.tplants.2005.10.002.

[55] Younes, I., Rinaudo, M. (2015): Chitin and chitosan preparation from marine sources. Structure, properties and applications. - Marine Drugs 13(3): 1133-1174. DOI:10.3390/md13031133.

[56] Yu, L., Zhang, C., Shang, H., Wang, X., Wei, M., Yang, F., Shi, Q. (2013): Exogenous hydrogen sulfide enhanced antioxidant capacity, amylase activities and salt tolerance of cucumber hypocotyls and radicles. - J. Integr Agric. 12(3): 445-456. 